\title{
Re: The Tunica Vaginalis Dorsal Graft Urethroplasty: Initial Experience
}

\author{
Roberto C. Foinquinos, Adriano A. Calado, Raimundo Janio, Adriana Griz, Antonio Macedo Jr, \\ Valdemar Ortiz
}

Division of Urology, State University of Pernambuco, Pernambuco, Brazil and Division of Urology, Federal University of Sao Paulo, Sao Paulo, Brazil

Int Braz J Urol, 33: 523-531, 2007

To the Editor:

After, in 1996, long term poor results of urethrotomy have been shown, urethral reconstruction procedures have significantly expanded. However, it is of interest that in US $(1,2), 93 \%$ of urologists perform still urethrotomy for the treatment of urethral strictures, while only a little minority (4.2\%) perform buccal mucosa urethroplasty.

The use of buccal mucosa is today the best available option for urethral reconstruction, and the high success rate of the procedure has probably slowed down the search for new urethral substitution materials. However, the search for the "graal" of the ideal urethral substitute is still active, including small intestinal submucosa (3), tongue mucosa (4), acellular matrix (5), which have been all proposed in recent years for urethroplasty. In the next future, tissue engineering might offer the definite answer (6).

The authors report they experience with tunica vaginalis urethroplasty in 11 male patients; in nearly half the patients, the urethral stricture was recurrent after urethrotomy.

The use of tunica vaginalis is not completely new. A pedicled tubularized flap of tunica vaginalis was used for urethral reconstruction in 1992 in 3 patients (7). Nevertheless, the tunica vaginalis has been used seldom, and always as a flap. This is the first report on the use of a free graft of tunica vaginalis for urethral reconstruction.

Though the seek for new urethroplasty options should be encouraged, we must emphasize that we have now long term (7-10 years) studies (8) on the results of buccal mucosa urethroplasty available.
As the authors rightly state, this study should be considered investigational, due to very short follow-up and the small number of cases.

To date, buccal mucosa urethroplasty should be the best graft procedure to offer to patients with bulbar (longer than $2 \mathrm{~cm}$ ) or penile stricture.

The authors used the dorsal approach popularized by Barbagli. Noteworthy, recently Barbagli himself (9) has questioned the real advantage of this approach compared to lateral and ventral approach.

We congratulate with the Brazilian Urology, which is very active in urethral reconstruction.

\section{REFERENCES}

1. Pansadoro V, Emiliozzi P: Internal urethrotomy in the management of anterior urethral strictures: long-term follow-up. J Urol. 1996; 156: 73-5.

2. Bullock TL, Brandes SB: Adult anterior urethral strictures: a national practice patterns survey of board certified urologists in the United States. J Urol. 2007; 177: 685-90.

3. Palminteri E, Berdondini E, Colombo F, Austoni E: Small intestinal submucosa (SIS) graft urethroplasty: short-term results. Eur Urol. 2007; 51: 1695-701.

4. Simonato A, Gregori A, Lissiani A, Galli S, Ottaviani F, Rossi R, et al.: The tongue as an alternative donor site for graft urethroplasty: a pilot study. J Urol. 2006; 175: 589-92.

5. El-Kassaby AW, Retik AB, Yoo JJ, Atala A: Urethral stricture repair with an off-the-shelf collagen matrix. J Urol. 2003; 169: 170-3. 
6. Atala A: Recent applications of regenerative medicine to urologic structures and related tissues. Curr Opin Urol. 2006; 16: 305-9.

7. Snow BW, Cartwright PC: Tunica vaginalis urethroplasty. Urology. 1992; 40: 442-5.

8. Fichtner J, Filipas D, Fisch M, Hohenfellner R, Thüroff JW: Long-term outcome of ventral buccal mucosa onlay graft urethroplasty for urethral stricture repair. Urology. 2004; 64: 648-50.

9. Barbagli G, Palminteri E, Guazzoni G, Montorsi F, Turini D, Lazzeri M: Bulbar urethroplasty using buccal mucosa grafts placed on the ventral, dorsal or lateral surface of the urethra: are results affected by the surgical technique? J Urol. 2005; 174: 955-7.

Dr. Vito Pansadoro Dr. Paolo Emiliozzi Casa di Cura Pio XI Rome, Italy E-mail: vitopansadoro@mclink.it 